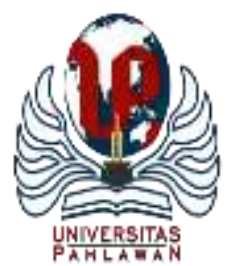

\title{
JURNALBASICEDU
}

Volume 6 Nomor 1 Tahun 2022 Halaman 515 - 523

Research \& Learningin Elementary Education https://jbasic.org/index.php/basicedu

\section{Pentingya Mitigasi Bencana Alam Longsor Lahan: Studi Persepsi Mahasiswa}

\author{
Siti Nurjanah ${ }^{1 凶}$, Enggal Mursalin $^{2}$ \\ Institut Agama Islam Negeri (IAIN) Ambon, Indonesia ${ }^{1,2}$ \\ E-mail: $\underline{\text { sitimology@ gmail.com }}{ }^{1}$, enggal.mursalin@iainambon.ac.id ${ }^{2}$
}

\begin{abstract}
Abstrak
Kota Ambon sebagai pusat bisnis dan pemerintahan di wilayah Provinsi Maluku memiliki karakteristik kondisi geografis yang tergolong daerah rawan bencana alam longsor lahan. Tercatat bahwa bencana alam longsor lahan termasuk ke dalam bencana alam tahunan yang kerap terjadi di Kota Ambon. Penelitian ini bertujuan untuk mengetahui persepsi mahasiswa Pendidikan Guru Madrasah Ibtidaiyah (PGMI) IAIN Ambon terhadap mitigasi bencana longsor lahan dalam upaya meminimalisir korban jiwa. Penelitian survei ini menggunakan metode deskriptif kualitatif persentase dalam pengolahan data. Pengambilan data dilakukan melalui penyebaran kuesioner kepada 82 mahasiswa aktif Program Studi PGMI IAIN Ambon. Hasil penelitian menunjukkan bahwa sebanyak 1) 63,41\% mahasiswa memiliki pengetahuan mitigasi bencana longsor lahan dalam kategori sangat baik; 2) 35,36\% mahasiswa dalam kategori baik, dan 3) 1,21\% mahasiswa dalam kategori cukup. Berdasarkan uraian tersebut, perlu diadakan sosialisasi dalam bentuk workshop, demonstrasi maupun simulasi lebih lanjut kepada segenap civitas akademika IAIN Ambon mengenai mitigasi bencana alam longsor lahan, sehingga diharapkan dapat meminimalisir adanya korban jiwa ketika bencana alam tersebut terjadi.
\end{abstract}

Kata kunci: persepsi, mitigasi bencana, longsor lahan.

\section{Abstract}

The city of Ambon as the center of business and government in the Maluku Province has the characteristics of geographical conditions that are classified as areas prone to landslides. It is noted that landslides are an annual natural disaster that often occurs in Ambon City. This study aims to determine the perception of students of Madrasah Ibtidaiyah Teacher Education (PGMI) IAIN Ambon on landslide disaster mitigation in an effort to minimize casualties. This survey research uses descriptive qualitative method of percentage in data processing. Data collection was carried out by distributing questionnaires to 82 active students of the PGMI IAIN Ambon Study Program. The results showed that 1) $63.41 \%$ of students had knowledge of landslide disaster mitigation in the very good category; 2) $35.36 \%$ of students in the good category, and 3) $1.21 \%$ of students in the moderate category. Based on this description, it is necessary to hold outreach in the form of workshops, demonstrations and further simulations to the entire academic community of IAIN Ambon regarding the mitigation of landslide natural disasters, so that it is hoped that there will be minimal casualties when the natural disaster occurs.

Keywords: perception, disaster mitigation, landslide

Copyright (c) 2022 Siti Nurjanah, Enggal Mursalin

$\triangle$ Corresponding author :

Email : sitimology@gmail.com

DOI : https://doi.org/10.31004/basicedu.v6i1.1937

ISSN 2580-3735 (Media Cetak)

ISSN 2580-1147 (Media Online) 
Pentingya Mitigasi Bencana Alam Longsor Lahan: Studi Persepsi Mahasiswa - Siti Nurjanah, Enggal Mursalin

DOI: https://doi.org/10.31004/basicedu.v6i1.1937

\section{PENDAHULUAN}

Secara geografis dan geologis Indonesia terletak di antara 2 (dua) samudera yakni Samudera Hindia dan Pasifik, dan 2 (dua) Benua yakni Benua Asia dan Australia, sekaligus terletak pada 2 (dua) lempeng bumi yakni lempeng benua Eurasia dan Indo-Australia. Di sisi lain, Indonesia juga merupakan negara kepulauan yang terletak diantara pertemuan tiga lempeng tektonik yaitu, lempeng Australia, Eurasia dan Pasifik. Kondisi tersebut menempatkan Indonesia menjadi salah satu Negara yang memiliki kerentanan terhadap bencana alam. Adapun bencana alam yang kerap terjadi di Indonesia yakni longsor lahan, banjir, gelombang tsunami, gempa bumi, letusan gunung api, puting beliung dan gelombang pasang air laut (Triatmadja, 2011; Sari, 2015; Puturuhu et al., 2017; Dwiyanti \& Subarkah, 2020; Sulaksana, Rendra, \& Sulastri, 2021; Sungkawa, 2011; Nugroho et al., 2018; Setyowati, 2019). Bencana alam longsor lahan merupakan bencana alam yang kerap terjadi di Indonesia setelah bencana banjir (Puturuhu et al., 2017).

Lebih lanjut, bencana alam merupakan suatu kejadian alam yang melalui proses alamiah ataupun non alamiah yang menyebabkan terjadinya korban jiwa, harta dan gangguan tatanan kehidupan (Setyowati, 2019). Peristiwa bencana memberikan dampak yang beranekaragam, sehingga sangat diperlukan upaya-upaya untuk menaggulanginya atau sering disebut mitigasi bencana. Mitigasi itu sendiri diartikan sebagai serangkaian upaya yang dilakukan untuk mengurangi risiko bencana, baik lewat pembangunan fisik ataupun penyadaran serta peningkatan kemampuan dalam menghadapi ancaman bencana (Suhardjo, 2011).

Lebih khusus, kondisi geografis Kota Ambon yang 75\% merupakan daerah perbukitan mengakibatkan sebagian besar masyarakat membangun di daerah berlereng dengan kemiringan lereng di atas $20 \%$, dimana hal tersebut berpotensi mengancam keselamatan nyawa jika terjadi bencana alam tanah longsor (Rakuasa \& Rifai, 2020). Diperkuat oleh hasil kajian BNPB yang menyebut bahwa Kota Ambon termasuk salah satu kota yang berpotensi mengalami bencana longsor lahan (BNPB, 2019). Selain kondisi geografisnya, intensitas curah hujan yang tinggi menjadi salah faktor dominan terjadinya longsor lahan. Kejadian longsor lahan yang terjadi di Kota Ambon yang terjadi setiap tahunnya sejak tahun 2010 sampai dengan tahun 2017 menyebabkan dampak dan kerugian yang sangat besar kepada masyarakat seperti kehilangan tempat tinggal hingga menelan korban jiwa. Bencana longsor lahan tidak hanya menyebabkan kerugian harta benda semata tetapi berdampak secara multidimensional, misalnya psikologi orang menjadi terganggu, relokasi pemukiman penduduk bahkan terganggunya investasi sebagai modal pembangunan ekonomi di kota Ambon (Dasmasela, Sembiring, \& Purnomo, 2020; Bimo, 2004).

Berdasarkan peta risiko bencana longsor Kota Ambon yang dirilis oleh BPBD Kota Ambon, didapatkan data bahwa tingkat risiko tinggi didominasi di wilayah Kecamatan Leitimur Selatan, Teluk Ambon dan diikuti oleh Kecamatan Nusaniwe dan hanya sebagaian kecil di Kecamatan Sirimau dan Kecamatan Teluk Ambon Baguala dikarenakan merupakan daerah perbukitan dan pegunungan dengan kemiringan lereng yang terjal. Pada tahun 2014 jumlah longsor lahan yang terjadi sebanyak 21 kejadian longsor lahan yang tersebar pada beberapa Kecamatan di Kota Ambon. Pada tahun 2015 jumlah kejadian longsor lahan meningkat drastis yaitu sebanyak 50 kejadian longsor lahan yang tersebar pada beberapa Kecamatan di Kota Ambon. Sedangkan pada tahun 2016 jumlah longsor lahan yang terjadi sebanyak 44 kejadian longsor lahan yang tersebar pada beberapa Kecamatan di Kota Ambon. Intensitas curah hujan yang tinggi menjadi faktor dominan terjadinya longsor lahan di Kota Ambon.

Kejadian longsor lahan di Kota Ambon yang selalu terjadi dari tahun ke tahun mengakibatkan kerugian bagi masyarakat sekitar bahkan menelan korban jiwa. Berdasarkan data Badan Penanggulan Bencana Daerah (BPBD) Kota Ambon, ada beberapa lokasi di Kota Ambon yang merupakan daerah yang berisiko terjadinya bencana longsor lahan dengan dampak kerusakan yang besar, yaitu Kelurahan Karang panjang, Sirimau, Kelurahan Batu gajah, Kelurahan Batu meja dan Kelurahan Batu merah (Latuconsina \& Priyono, 2019). Berdasarkan hasil analisis akhir penelitian tentang kerentanan tanah longsor, maka Kota Ambon dapat dibagi 
Pentingya Mitigasi Bencana Alam Longsor Lahan: Studi Persepsi Mahasiswa - Siti Nurjanah, Enggal Mursalin

DOI: https://doi.org/10.31004/basicedu.v6i1.1937

menjadi 3 zona kerentanan tanah longsor, yaitu: Zona tanah longsor Rendah, mempunyai luas \pm 5.957,67 ha $(17,81 \%)$, Zona tanah longsor Sedang, mempunyai luas \pm 18.5 (Rakuasa \& Rifai, 2020).

Faktor penyebab terjadinya longsor lahan karena proses perubahan struktur permukaan bumi yang ditandai dengan adanya gangguan kestabilan pada tanah dan batuan penyusun lereng yang keduanya dipengaruhi oleh kondisi geomorfologi terutama faktor kemiringan lereng, kondisi batuan ataupun tanah penyusun lereng, dan kondisi hidrologi pada daerah lereng. Sedangkan faktor dominan penyebab longsor lahan yaitu, (1) kondisi topografi pada daerah tersebut yang merupakan daerah perbukitan dengan kemiringan terjal (30-45') dimana semakin terjal kemiringan suatu lereng akan semakin besar gaya penggerak massa tanah atau batuan penyusun lereng sehingga lebih berisiko terjadi longsor lahan; (2) keadaan tanah dimana tanah jenuh karena air hujan sehingga akan berpengaruh pada kesetabilan tanah (Karnawati, 2005; Pánek et al., 2019). Kondisi tanah yang tidak stabil akan lebih mudah runtuh dan menuruni lereng (Li et al., 2019). Selain faktor alam, faktor lain yang memicu terjadinya longsor lahan juga disebabkan oleh manusia sendiri, beberapa hal yang penyebab longsor lahan yang disebabkan oleh manusia yakni, (1) pemotongan tebing di lereng pegunungan, (2) penimbunan di daerah lereng, (3) penebangan pohon tanpa tebang pilih, (4) kurangnya kecintaan masyarakat terhadap lingkungan sekitar, (5) pengembangan wilayah yang tidak sesuai, dan sistem irigasi serta pertanian yang tidak memperhatikan keamanan (Ramli, 2010).

Berdasarkan pengamatan diperoleh informasi bahwa pada daerah terjadinya longsor lahan terdapat aktivitas manusia berupa pola penggunaan lahan yang tidak sesuai, yaitu melakukan pemotongan lereng untuk permukiman dan jalan yang dapat mengakibatkan hilangnya peneguh lereng yang akhirnya dapat memicu terjadinya longsor lahan pada lereng. Selain itu, pola hidup masyarakat seperti membuang sampah sembarangan dan pengembangan wilayah yang tidak sesuai dengan peruntukannya serta tidak diimbangi dengan kesadaran masyarakat sehingga menimbulkan masalah lingkungan. Kejadian longsor lahan yang sering terjadi di Kota Ambon berdampak besar bukan hanya berdampak terhadap lingkungan tetapi juga berdampak besar terhadap tatanan kehidupan masyarakatnya, yaitu (1) rusaknya perumahan penduduk, (2) masyarakat kehilangan tempat tinggal, (3) rusaknya infrastruktur publik seperti jalan dan jembatan, menghambat aktivitas masyarakat dan merugikan masyarakat yang tinggal di daerah bencana dan sekitarnya bahkan bencana longsor lahan mengakibatkan korban jiwa. Kejadian longor lahan yang berdampak sangat besar seperti jatuhnya korban jiwa dan kerugian materiil dapat dan perlu dicegah yaitu dengan upaya-upaya mitigasi longsor lahan dengan tujuan untuk dapat mencegah, meminimalkan terjadinya korban dan kerugian longsor lahan yang disebabkan karena merupakan suatu proses alamiah.

Kerugian yang diakibatkan oleh bencana alam biasanya disebabkan karena pemahaman masyarakat pada upaya mengurangi risiko atau dikenal dengan mitigasi bencana masih rendah. Mitigasi bencana sangat diperlukan untuk mengurangi kerentanan terhadap bencana tersebut. Berdasarkan Indeks Risiko Bencana Indonesia (IRBI) 2018, Kota Ambon memiliki indeks risiko bencana tanah longsor 8.5 kategori sedang (Nugroho et al., 2018). Perlu dilakukan upaya mitigasi untuk meminimalisir dampak dari bencana longsor yaitu identifikasi daerah yang rentan terhadap bencana longsor (Bayuaji, Nugraha, \& Sukmono, 2016). Kerentanan merupakan kondisi suatu komunitas yang menyebabkan ketidak mampuan dalam menghadapi bahaya. Kesiapsiagaan masayarakat merupakan bagian dari pengurangan risiko bencana sebagai upaya untuk membangun ketahanan masyarakat.

Mitigasi bencana menjadi tanggungjawab bersama yang termasuk di dalamnya mahasiswa. Peran mahasiswa sangat dibutuhkan sebagai bagian dari masyarakat. Mahasiswa diharapkan memiliki sikap dan persepsi serta kewaspadaan dalam upaya mengurangi risiko bencana. Persepsi setiap individu terhadap suatu stimulus memiliki keberagaman yang dipengaruhi oleh faktor-faktor tertentu. Faktor-faktor tersebut secara garis besar terdiri dari faktor fungsional dan faktor non struktural (Rakhmat, 2011). Faktor fungsional merupakan faktor yang berasal dari kebutuhan pribadi atau personal yang didapatkan dari masalalunya. Sedangkan faktor non struktural merupakan sifat stimulasi fisik dari efek yang ditimbulkan. Dari pengertian di 
atas dapat disimpulkan bahwa terdapat faktor yang mempengaruhi persepsi yakni intensitas stimulus, objekobjek yang memenuhi tujuan individu untuk melakukan persepsi, pemahaman stimulus, dan motivasi personal. Proses timbulnya persepsi berkaitan erat dengan inderawi individu. Panca indera berperan merespon stimulus yang kemudian diintepretasikan pada gagasan personal sehingga terciptanya persepsi.

Terdapat ciri khas dalam penelitian ini yakni menggali persepsi mahasiswa terhadap adanya mitigasi bencana longsor lahan, hal ini diwujudkan dalam perkuliahan dengan memberikan materi terkait mitigasi longsor lahan untuk menumbuhkan pengetahuan mahasiswa mengenai longsor lahan. Matakuliah yang digunakan sebagai wadah untuk kegiatan penelitian ini yakni matakuliah konsep dasar IPS. Mata kuliah konsep dasar IPS merupakan matakuliah yang mengkaji beberapa fenomena alam dan sosial yang terjadi di lingkungan sekitar, hal ini relevan dengan bahasan kajian mengenai longsor lahan yang melibatkan fenomena alam dan fenomena sosial. Fenomena longor lahan di Ambon sering terjadi dan menimbulkan bebarapa korban baik secara materiil maupun non materil, hal inilah yang mendasari mengapa perlunya edukasi terkait longsor lahan (Kesaulya, Poli, \& Takumansang, 2016). Melalui mata kuliah diharapkan mahasiswa memiliki pengetahun umum mengenai penyebab, dampak dan cara mengurangi risiko suatu dampak. Mahasiswa diharapkan memiliki persepsi terhadap mitigasi bencana lahan longsor yang secara umum memiliki karakteristik asal daerah masing-masing sehingga diharapkan akan banyak persepsi yang dapat diungkapkan. Persepsi mahasiswa diharapkan dapat membentuk respon yang positif dikalangan mahasiswa terhadap mitigasi bencana lahan longsor. Selain itu persepsi tentang longsor lahan dapat dijadikansebagai bahan pertimbangan untuk menentukan langkah kongkrit dalam penanganan dampak bencana longsor lahan baik dilingkungan masyarakat ataupun di lembaga-lembaga pendidikan formal sebagai wadah penyaluran informasi dan edukasi. Oleh karena itu peneliti tertarik untuk meneliti persepsi mahasiswa Pendidikan Guru Madrasah Ibtidayah IAIN Ambon terhadap mitigasi bencana alam longsor lahan.

\section{METODE PENELITIAN}

Penelitian ini merupakan penelitian survei dengan pendekatan deskriptif kualitatif. Penelitian deskriptif yaitu penelitian yang mengamati sesuatu (objek penelitian) dan kemudian menjelaskan gejala-gejala, faktafakta, atau kejadian secara sistematis dan akurat yang sesuai dengan keadaan yang sebenarnya (Sugiyono, 2016). Tujuan dari penelitian ini adalah untuk mengetahui persepsi mahasiswa PGMI IAIN Ambon terhadap mitigasi bencana longsor lahan. Sasaran dalam penelitian ini yakni mahasiswa PGMI IAIN Ambon yang mengambil matakuliah konsep dasar IPS, pengajar matakuliah, dan informan data sekunder penelitian. Alasan mendasar mengapa melalui matakuliah konsep dasar IPS penelitian ini dilakukan yakni matakuliah ini secara mendasar membahas mengenai fenomena alam dan sosial yang terhadi dilingkungan sekitar sehingga relevan terhadap penelitian yang dikaji. Diharapkan melalui edukasi mitigasi longsor lahan mahasiswa memiliki pengetahuan umum mengenai longsor lahan, penyebab, dampak dan cara pencegahan dampak longsor lahan. Selain itu mahasiswa melalui pemahaman longsor lahan dapat memiliki keterampilan dasar IPS yakni kemampuan menerima informasi, menganalisis dan mengintrepretasikan pemahaman tersebut.

Teknik pengumpulan data dalam penelitian ini melalui observasi, wawancara dan dokumentasi. Pengumpulan data kualitatif dilakukan dengan beberapa langkah yakni melakukan observasi data sekunder melalui peninjauan pengetahuan awal mahasiswa terkait longsor lahan, memberikan materi terkait longsor lahan berupa fenomena-fenomena longsor lahan di berbagai daerah sekitar. Selain diberikan materi mahasiswa diberikan pengetahuan untuk menganalisis berdasarkan fakta tentang lokasi longsor lahan, penyebab dan dampaknya sehingga memunculkan pemahaman tertentu yang membangkitkan keterampilan dasar IPS mahasiswa. Pengumpulan data sekunder yang kedua yakni melalui teknik wawancara dengan dengan menggunakan instrumen penelitian yang disiapkan untuk menggali persepsi mahasiswa. Data tersebut 
Pentingya Mitigasi Bencana Alam Longsor Lahan: Studi Persepsi Mahasiswa - Siti Nurjanah, Enggal Mursalin

DOI: https://doi.org/10.31004/basicedu.v6i1.1937

diproses kembali yang dipersiapkan untuk memperoleh data kualitatif. Pengumpulan data kualitatif ini merujuk pada angket yang telah dipersiapkan dengan indiator-indikator tertentu.

Teknik analisa data Hal ini didapatkan melalui proses reduction (reduksi data), data display (penyajian data), data conclusion drawing/verification (penarikan kesimpulan) (Moleong, 2017). Analisa data dilakukan secara berkelanjutan dan interaktif sampai menemukan tahap perolehan data yang diinginkan. Data deskriptif kualitatif dalam penelitian ini disajikan dengan menggunakan bentuk data persentase sesuai data yang diperoleh saat penelitian. Adapun pengukuran instrumen likert pengukuran sikap yang berisi daftar pertanyaan dengan tingkat respon sangat setuju sampai tidak setuju. Adapun pilihan jawaban untuk angket penelitian terdiri dapi 4 (empat) alternatif jawaban (1) sangat baik, (2) baik, (3) cukup, dan (4) kurang baik.

\section{HASIL DAN PEMBAHASAN}

Persepsi dimaknai sebagai pengalaman tentang objek, peristiwa, atau hubungan-hubungan yang diperoleh dengan menyimpulkan informasi dan menafsirkan pesan. Persepsi ialah memberikan makna pada stimulus inderawi atau sensory stimulus (Rakhmat, 2011). Selanjutnya, persepsi merupakan suatu proses pemahaman atau pemberian makna atas suatu informasi terhadap stimulus atau faktor pendorong. Persepsi dapat dipengaruhi oleh tiga faktor yakni pengetahuan, keyakinan dan pengalaman (Astari \& Ramadan, 2022). Seseorang membutuhkan pengalaman untuk mendapati persepsi yang dapat dipelajari melalui interaksi dengan lingkungan.

Mitigasi menurut Somantri (dalam Puturuhu, 2015) adalah suatu usaha memperkecil jatuhnya korban manusia dan atau kerugian harta benda akibat peristiwa atau rangkaian peristiwa yang disebabkan oleh alam, manusia dan keduanya yang mengakibatkan jatuhnya korban, penderitaan manusia, kerugian harta benda, kerusakan sarana prasarana dan fasilitas umum serta menimbulkan gangguan terhadap tata kehidupan dan penghidupan masyarakat. Mitigasi bencana terbagi menjadi dua jenis yakni mitigasi secara fisik yang merupakan tindakan fisik mengurangi risiko bencana sedangkan mitigasi non fisik merupakan tindakan mengurangi risiko bencana melalui tindakan non fisik yang diwujudkan dalam pendidikan mitigasi bencana. Risiko bencana yang dimaksud ini meliputi timbulnya korban jiwa, kerusakan lingkungan, hilangnya dan kerugian harta benda (rumah, perabotan dan lain-lain) serta timbulnya dampak psikologis. Dapat disimpulkan bahwa mitigasi bencana merupakan tindakan yang dilakukan untuk menghilangkan atau mengurangi dampak serta risiko bahaya lewat tindakan proaktif yang diambil sebelum bencana terjadi. Pengetahuan tentang kesiapsiagaan bencana, pemahaman terhadap mitigasi bencana sangat diperlukan untuk menghadapi bencana longsor lahan (Rahmat et al., 2020).

Pada prinsipnya, pendidikan mitigasi bencana satuan pendidikan bergantung pada kemampuan pendidik dalam mengintegrasikan permasalahan di lingkungan sekitar ke dalam materi pembelajaran guna menumbuhkan kesadaran peserta didik tentang pentingnya menjaga lingkungan (Mursalin, 2015; Hayudityas, 2020). Mitigasi bencana terdiri dari tiga hal yakni tindakan sebelum terjadinya bencana, saat terjadinya bencana dan setelah terjadinya bencana (Ramli, 2010; Suhardjo, 2011). Pendidikan mitigasi bencana pada tahap sebelum terjadinya bencana mencakup tindakan preventif dan tindakan persiapan, seperti persiapan jalur evakuasi, lahan sementara, pangaturan tata guna lahan dan penghijauan. Tahap kedua yakni pendidikan mitigasi bencana saat terjadinya bencana yakni ditunjukan dengan sikap tanggap bencana seperti upaya dalam menanggapi peristiwa, menyelamatkan diri, dan mengkondisikan psikologis masing-masing. Tahap terakhir dalam mitigasi bencana adalah tindakan setelah terjadinya bencana. Beberapa tindakan yang dapat dilakukan yakni dengan langkah evaluasi dan mitigasi peringatan dini (Srividhya et al., 2020).

Berdasarkan hasil penelitian dapat diketahui bahwa persepsi 82 mahasiswa PGMI IAIN Ambon terhadap pentingnya peranan mitigasi bencana longsor lahan sehingga perlu dilakukan, yakni sebagai berikut, (1) kategori sangat baik berjumlah 63,41\%,(2) kategori baik berjumlah 35,36\%, (3) kategori cukup berjumlah 
Pentingya Mitigasi Bencana Alam Longsor Lahan: Studi Persepsi Mahasiswa - Siti Nurjanah, Enggal Mursalin

DOI: https://doi.org/10.31004/basicedu.v6i1.1937

$1,21 \%$, dan (4) kelompok kurang berjumlah 0\%. Data tersebut dapat digambarkan seperti pada diagram di bawah ini.

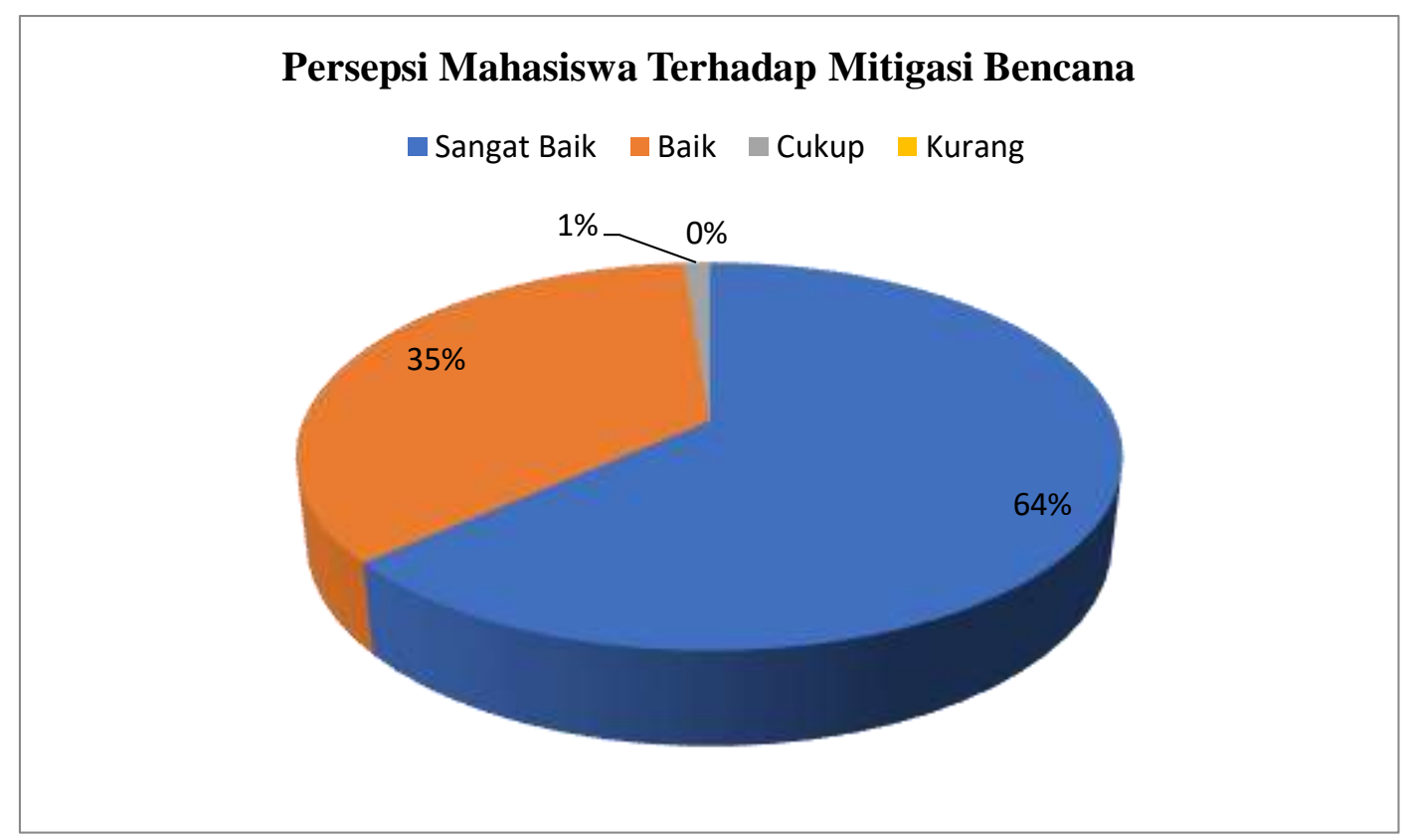

\section{Gambar 1: Persepsi Mahasiswa Terhadap Mitigasi Bencana}

Persepsi terhadap mitigasi bencana sangat penting untuk mengetahui tingkat pemahaman dan pengetahuan mahasiswa tentang mitigasi bencana. Berdasarkan data tersebut dapat ditarik suatu kesimpulan bahwa persepsi mahasiswa terhadap mitigasi bencana longsor lahan sangat diperlukan di Perguruan Tinggi. Hal ini menunjukkan bahawa kesadaran untuk mengurangi risiko bencana semakin tinggi. Mitigasi secara struktural fungsional sangat diperlukan untuk dilakukan di perguruan tinggi dengan mendasarkan bahwa perguruan tingi merupakan lembaga formal yang memiliki peran terhadap adanya pemahaman mitigasi bencana longsor lahan atau pengurangan dampak longsor lahan. Pendidikan mitigasi bencana pada tahap sebelum terjadinya bencana mencakup tindakan preventif dan tindakan persiapan, seperti persiapan jalur evakuasi, lahan sementara, pengaturan tata guna lahan dan penghijauan pada daerah perbukitan dan lereng. Tahap kedua yakni pendidikan mitigasi bencana saat terjadinya bencana yakni ditunjukan dengan sikap tanggap bencana seperti upaya dalam menanggapi peristiwa, menyelamatkan diri, dan mengkondisikan psikologis masing-masing. Tahap terakhir dalam mitigasi bencana adalah tindakan setelah terjadinya bencana. Beberapa tindakan yang dapat dilakukan yakni dengan langkah evaluasi dan mitigasi peringatan dini.

Persepsi mahasiswa terhadap mitigasi struktural fungsional ini terdiri dari beberapa hal yang sifatnya penanggulangan secara tersistem seperti, diperlukan jalur evakuasi bencana, pembuatan papan petunjuk jalur evakuasi, perbaikan bangunan perkuliahan dan sarana pendukung di sekitar kampus dengan bangunan tahan terhadap bahaya longsor lahan, diperlukan strategi peringatan dini terjadinya bencana, menyediakan relokasi sementara untuk permukiman sementara layak huni, membuat tanggul atau talud penahan tanah pada daerah yang rawan longsor lahan, penataan ulang sistem drainase, melakukan pemantauan secara berkala di daerah rawan longsor, membuat perencanaan terhadap bencana longsor lahan yang kemungkinan disebabkan bukan karena faktor alami (Rahmat et al., 2020).

Tujuan lain dari mitigasi bencana, yakni meningkatkan pengetahuan seseorang dalam menghadapi dan mengurangi risiko bencana, supaya masyarakat dapat hidup dengan aman dan nyaman. Mitigasi bencana juga ditujukan sebagai landasan perencanaan pembangunan (Wibowo \& Taat Wulandari, 2014; Puturuhu, 2015). Oleh karenanya mitigasi bencana dalam pendidikan sangat diperlukan. Untuk menghadapi bencana alam agar 
tidak terlalu banyak makan korban manusia dan menimbulkan kerugian sosial ekonomi, maka pendidikan kebencanaan menjadi kebutuhan mendesak (Mustadi \& Atmojo, 2020). Sudah saatnya dunia pendidikan dengan serius mengembangkan sebuah kurikulum dan pembelajaran untuk pendidikan kebencanaan bagi para peserta didik yang saat ini jumlahnya mencapai puluhan juta di seluruh tanah air.

Persepsi mahasiswa terhadap mitigasi bencana longsor lahan yang dilihat dari aspek mitigasi secara non struktural dapat disimpulkan dalam beberapa kategori yakni (1) kategori sangat baik sebesar 58,53\%, (2) kategori baik sebesar 40,24\%, (3) kategori cukup sebesar 1,21\% dan kategori kurang sebesar 0\%. Dari hasil penelitian ini dapat disimpulkan bahwa mahasiswa memiliki persepsi yang sangat baik terdapat bentuk mitigasi longsor lahan pada aspek nonstruktural. Pendidikan mitigasi yakni terdiri dari mitigasi sebelum terjadi bencana, saat terjadi bencana dan sesudah terjadinya bencana.

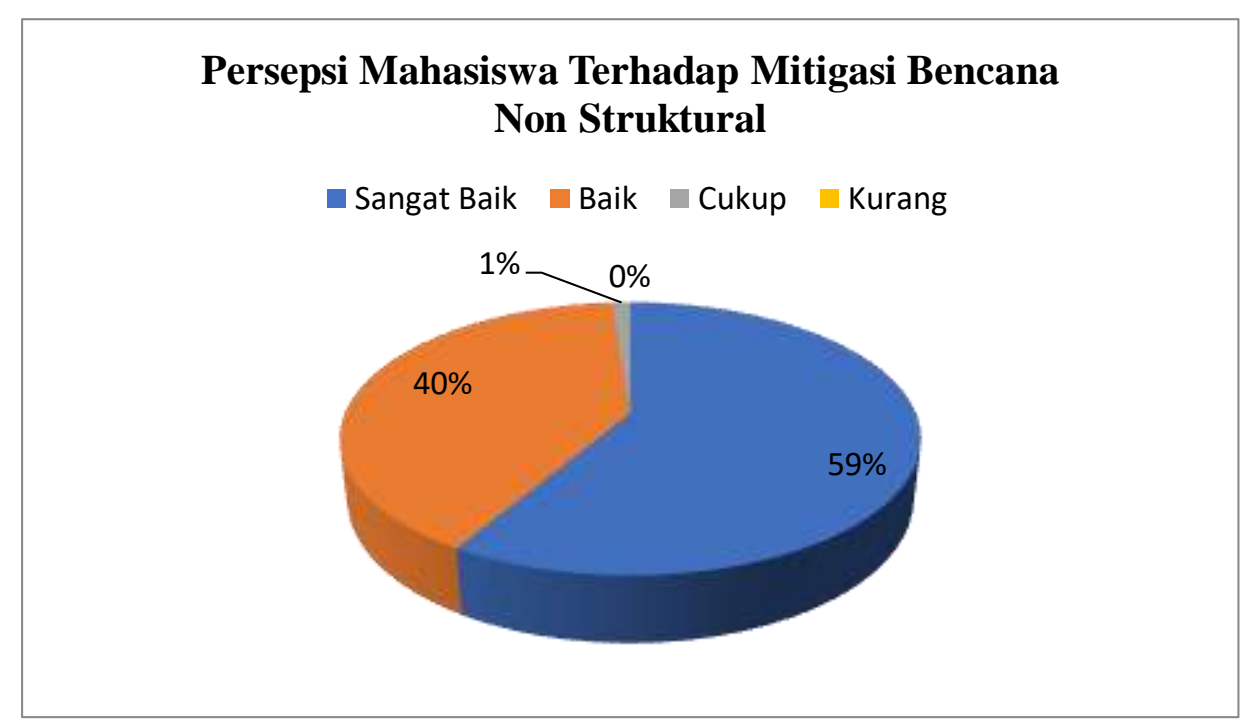

Gambar 2: Persepsi Mahasiswa Terhadap Mitigasi Bencana Non Struktural

Pada tahap sebelum terjadinya bencana persepsi mahasiswa terkait dengan perlunya pemahaman dan sosialisasi secara lengkap tentang gejala awal longsor lahan yakni sebesar 58,53\%, perlunya memberikan penyuluhan mengenai dampak penggunalan lahan yang terdapat di daerah rawan bencana longsor lahan sebesar $62,19 \%$, menyediakan informasi terkait pemetaan daerah-daerah yang rawan longsor lahan sebesar $63,41 \%$, dan perlunya pengawasan kepada masyarakat untuk ikut menjaga kelestarian lingkungan dengan melakukan reboisasi dan tidak melakukan penebangan pohon di daerah lereng sebesar $40,24 \%$, pengelolaan tataguna lahan serta memperhatikan kelestarian lingkungan sebesar 56,09\%, membuat peraturan daerah terkait dengan penggunaan lahan layak huni sebesar $62,19 \%$.

Selain hal di atas Persepsi mahasiswa PGMI IAIN Ambon pada tahap terjadinya bencana sangat setuju bahwa ketika terjadinya bencana harus tenang atau tidak panik dan segera ke tempat yang aman dari longsoran sebesar $58,53 \%$, persepsi mementingkan untuk membantu balita lansia dan orang yang mengalami cedera sebesar 63,41\%, menuju ke lokasi evakuasi sementara sebesar 56,09 \%, menyediakan dukungan logistik darurat sementara sebesar 62,19\%, menghubungi pihak-pihak yang memiliki kewenangan terhadap penanggulangan bencana sebesar $62,19 \%$.

Manajemen bencana merupakan beberapa kegiatan penangulangan bencana yang terbagi menjadi tiga bagian yakni sebelum, saat dan sesudah terjadinya bencana (Suwaryo \& Yuwono, 2017; Suharini, Kurniawan, \& Ichsan, 2020). Dari hasil penelitian terhadap persepsi mahasiswa menganggap bahwa indikator penanggulangan bencana pada tahap tersebut sangat diperlukan dan merupakan langkah penting dalam mengurangi dan mencegah banyaknya korban ketika bencana terjadi. Hal ini sejalan dengan beberapa 
Pentingya Mitigasi Bencana Alam Longsor Lahan: Studi Persepsi Mahasiswa - Siti Nurjanah, Enggal Mursalin

DOI: https://doi.org/10.31004/basicedu.v6i1.1937

penelitian mengenai faktor yang mempengaruhi bencana longsor lahan. Sangat diperlukan beberapa penelitian lebih lanjut mengenai teknik-teknik terbaru dalam sosialisasi atau edukasi mitigasi bencana longsor lahan secara luas agar membangun kesadaran pentingnya mitigasi bencana dan diperlukan bimbingan kepada seluruh lapisan masyarakat dalam membangun persepsi mitigasi longsor lahan secara berkala hal ini digunakan untuk mengurangi risiko terjadinya longsor lahan.

\section{KESIMPULAN}

Berdasarkan uraian hasil penelitian ini, dapat disimpulkan bahwa mahasiswa PGMI IAIN Ambon menganggap pentingnya peranan mitigasi bencana alam longsor lahan baik dari segi aspek fungsional struktural maupun nonstruktural. Melalui pemahaman akan mitigasi bencana alam longsor lahan yang baik, diharapkan mahasiswa memiliki keterampilan dasar penguasaan ilmu pengetahuan sosial yang meliputi keterampilan dasar dalam menerima informasi, menganalisis informasi dan mengintrepretasikan pengetahuan tersebut dalam kehidupan sehari-hari. Namun demikian, pemahaman akan mitigasi bencana alam selain longsor lahan pun perlu lebih intensif lagi diberikan seperti bencana gempa bumi, tsunami, dan banjir.

\section{DAFTAR PUSTAKA}

Astari, M., \& Ramadan, Z. H. (2022). Persepsi Orang Tua Terhadap Pembelajaran Daring Di Masa Pandemi Covid-19 Di Sekolah Dasar. Jurnal Basicedu, 6(1), 230-241.

Bayuaji, D. G., Nugraha, A. L., \& Sukmono, A. (2016). Analisis Penentuan Zonasi Risiko Bencana Tanah Longsor Berbasis Sistem Informasi Geografis (Studi Kasus: Kabupaten Banjarnegara). Jurnal Geodesi Undip, 5(1), 326-335.

Bimo, W. (2004). Pengantar Psikologi Umum. In Jakarta: Andi.

Dasmasela, C. R. C., Sembiring, I., \& Purnomo, H. D. (2020). Sistem Peringatan Dini Rawan Bencana Longsor Di Kota Ambon Menggunakan Iot. Jsinbis (Jurnal Sistem Informasi Bisnis), 10(2), 220-227.

Dwiyanti, L. A., \& Subarkah, A. (2020). Kerentanan Masyarakat Kampung 200 Terhadap Ancaman Tanah Longsor Di Kelurahan Dago Kecamatan Coblong Kota Bandung. Jurnal Ilmiah Perlindungan \& Pemberdayaan Sosial, 2(2).

Hayudityas, B. (2020). Pentingnya Penerapan Pendidikan Mitigasi Bencana Di Sekolah Untuk Mengetahui Kesiapsiagaan Peserta Didik. Jurnal Edukasi Nonformal, 1(2), 94-102.

Karnawati, D. (2005). Geologi Umum Dan Teknik.

Kesaulya, H. M., Poli, H., \& Takumansang, E. D. (2016). Perencanaan Mitigasi Bencana Longsor Di Kota Ambon. Spasial, 3(3), 228-235.

Latuconsina, H., \& Priyono, K. D. (2019). Analisis Spasial Dan Persepsi Masyarakat Dalam Upaya Mitigasi Bencana Longsor lahan Di Kota Ambon Provinsi Maluku. Universitas Muhammadiyah Surakarta.

Li, C., Fu, Z., Wang, Y., Tang, H., Yan, J., Gong, W., ... Criss, R. E. (2019). Susceptibility Of ReservoirInduced Landslides And Strategies For Increasing The Slope Stability In The Three Gorges Reservoir Area: Zigui Basin As An Example. Engineering Geology, 261, 105279.

Moleong, L. J. (2017). Metode Penelitian Kualitatif, Cetakan Ke-36. In Pt. Remaja Rosdakarya Offset. Bandung.

Mursalin, E. (2015). Pengembangan Bahan Ajar Bervisi Sets (Science, Environment, Technology And Society) Dan Berbasis Kewirausahaan Kimia (Chemoentrepreneurship) Kompetensi Terkait Hidrokarbon Dan Minyak Bumi. Majalah Ilmiah Pawiyatan, 22(2), 113-127.

Mustadi, A., \& Atmojo, S. E. (2020). Student's Disaster Literation In'sets'(Science Environment Technology 
Pentingya Mitigasi Bencana Alam Longsor Lahan: Studi Persepsi Mahasiswa - Siti Nurjanah, Enggal Mursalin

DOI: https://doi.org/10.31004/basicedu.v6i1.1937

And Society) Disaster Learning. Ilkogretim Online, 19(2).

Nugroho, P. C., Pinuji, S. E., Ichwana, A. N., Nugraha, A., Wiguna, S., Randongkir, R. E., Hafiz, A. (2018). Indeks Resiko Bencana Indonesia Tahun 2018. Bnpb Jakarta.

Pánek, T., Břežný, M., Kapustová, V., Lenart, J., \& Chalupa, V. (2019). Large Landslides And Deep-Seated Gravitational Slope Deformations In The Czech Flysch Carpathians: New Lidar-Based Inventory. Geomorphology, 346, 106852.

Puturuhu, F. (2015). Mitigasi Bencana Dan Penginderaan Jauh. In Yogyakarta: Graha Ilmu.

Puturuhu, F., Danoedoro, P., Sartohadi, J., \& Srihadmoko, D. (2017). The Development Of Interpretataion Method For Remote Sensing Imagery In Determining The Candidate Of Landslide In Leitimur Paninsula, Ambon Island. Jurnal Ilmu Lingkungan, 15(1), 20-34.

Rahmat, H. K., Pratikno, H., Gustaman, F. A. I., \& Dirhamsyah, D. (2020). Persepsi Risiko Dan Kesiapsiagaan Rumah Tangga Dalam Menghadapi Bencana Tanah Longsor Di Kecamatan Sukaraja Kabupaten Bogor. Sosiohumaniora: Jurnal Ilmiah Ilmu Sosial Dan Humaniora, 6(2), 25-31.

Rakhmat, J. (2011). Psikologi Komunikasi. Remaja Rosdakarya.

Rakuasa, H., \& Rifai, A. (2020). Pemetaan Kerentanan Bencana Tanah Longsor Berbasis Sistem Informasi Geografis Di Kota Ambon. Seminar Nasional Geomatika, 327-336.

Ramli, S. (2010). Pedoman Praktis Manajemen Bencana. Dian Rakyat.

Sari, K. D. A. (2015). Pusat Pelatihan Dan Simulasi Bencana Alam Nasional Di Yogyakarta (Dengan Pendekatan Desain Arsitektur Post Modern Dan Perilaku). Universitas Negeri Semarang.

Setyowati, D. L. (2019). Pendidikan Kebencanaan. In Universitas Negeri Semarang.

Srividhya, K., Mohan, A., Tholkapiyan, M., \& Arunraj, A. (2020). Earth Quake Disaster Mitigation (Eqdm) Through Engineering Design. Materials Today: Proceedings, 22, 1074-1077.

Sugiyono. (2016). Metode Penelitian Manajemen (Pendekatan Kuantitatif, Kualitatif, Kombinasi (Mixed Methods), Penelitian Tindakan (Action Research, Dan Penelitian Evaluasi). In Bandung: Alfabeta Cv.

Suhardjo, D. (2011). Arti Penting Pendidikan Mitigasi Bencana Dalam Mengurangi Resiko Bencana. Jurnal Cakrawala Pendidikan, (2).

Suharini, E., Kurniawan, E., \& Ichsan, I. Z. (2020). Disaster Mitigation Education In The Covid-19 Pandemic: A Case Study In Indonesia. Sustainability: The Journal Of Record, 13(6), 292-298.

Sulaksana, N., Rendra, P. P. R., \& Sulastri, M. (2021). Sosialisasi Mitigasi Bencana Longsor Dan Banjir Secara Virtual Di Masa Pandemi Covid-19. Kumawula: Jurnal Pengabdian Kepada Masyarakat, 4(3), $465-470$.

Sungkawa, D. (2011). Letak Indonesia (Jurnal).

Suwaryo, P. A. W., \& Yuwono, P. (2017). Faktor-Faktor Yang Mempengaruhi Tingkat Pengetahuan Masyarakat Dalam Mitigasi Bencana Alam Tanah Longsor. Urecol, 305-314.

Triatmadja, R. (2011). Tsunami: Kejadian, Penjalaran, Daya Rusak, Dan Mitigasinya. Gadjah Mada University Press.

Wibowo, S., \& Taat Wulandari, S. (2014). Persepsi Mahasiswa Pendidikan Ips Terhadap Mitigasi Bencana Gempa Bumi. Jipsindo, 1(2), 161-182. 